\title{
18. PROVENANCE OF DETRITAL SEDIMENTS FROM THE MIDDLE AMERICA TRENCH TRANSECT OFF GUATEMALA, DEEP SEA DRILLING PROJECT LEG 671
}

\author{
Sachindra Prasad ${ }^{2}$ and Reinhard Hesse, Department of Geological Sciences, McGill University, \\ Montreal, Quebec, Canada
}

\begin{abstract}
Heavy and light minerals were examined in 29 samples from Sites 494, 498, 499, 500, and 495 on the Deep Sea Drilling Project Leg 67 Middle America Trench transect; these sites represent lower slope, trench, and oceanic crust environments off Guatemala. All samples are Quaternary except those from Hole 494A (Pliocene) and Hole 498A (Miocene). Heavy-mineral assemblages of the Quaternary sediments are characterized by an immature pyroxene-amphibole suite with small quantities of olivine and epidote. The Miocene sediments yielded an assemblage dominated by epidote and pyroxene but lacking olivine; the absence of olivine is attributed to selective removal of the most unstable components by intrastratal solution. Light-mineral assemblages of all samples are predominantly characterized by volcanic glass and plagioclase feldspar. The feldspar compositions are compatible with andesitic source rocks and frequently exhibit oscillatory zoning. The heavy- and light-mineral associations of these sediments suggest a proximal volcanic source, most probably the Neogene highland volcanic province of Guatemala. Sand-sized components from Site 495 are mainly biogenic skeletons and volcanic glass and, in one instance (Section 495-5-3), euhedral crystals of gypsum.
\end{abstract}

\section{INTRODUCTION}

Drilling was done at seven sites on the Deep Sea Drilling Project Middle America Trench transect in the area of San José Canyon off Guatemala (Fig. 1). Cores recovered from the sedimentary sequence on the slope (from Holes 494, 494A, 496, 497, 498, and 498A) consist of diatomaceous, terrigenous muds and mudstone interstratified with ash layers, diagenetic carbonates, and some coarser, sandy, terrigenous material. In the Trench (Sites 499, 500), a sequence of Quaternary turbidites and interlayered hemipelagic muds overlies Quaternary to Miocene hemipelagic and pelagic sediments that are equivalent to those (greenish gray hemipelagic mud; brown abyssal clay; nannofossil ooze, chalk, and limestone; and manganiferous limestone) recovered at the Cocos Plate reference site (495). In order to confirm that the Trench and slope sediments are derived from the nearby volcanic province of Guatemala, heavy and light minerals of the sand fraction were studied. At Sites 499 and 500 , turbidity currents flowing along the Trench axis might have brought in significant amounts of sediments from more distal sources such as Mexico. The objective of this study, therefore, was to discriminate between various possible source areas. Another objective was to provide supporting evidence for the source of the slope sediments. Are they trench-derived, as the tectonic model for trench-slope accretion postulates (Seely et al., 1974), or are they accumulated by downslope processes? Provenance is of particular interest because the orderly stratigraphic sequence encountered at Site 494

\footnotetext{
${ }^{1}$ Aubouin, J., von Huene, R., et al., Init. Repts. DSDP, 67: Washington (U.S. Govt. Printing Office)

2 Present address: Rosenstiel School of Marine and Atmospheric Science, Division of Marine Geology and Geophysics, University of Miami, Miami, Florida.
}

(see Site 494 report, this volume) cannot easily be reconciled with an imbricate stack of thrust slices that are the result of the off-scraping of pelagic sediments and trench deposits from the subducting Plate, as proposed by Seely et al. (1974) and Seely (1979). A third objective was to describe physical properties of mineral grains that might give clues to their diagenetic alteration.

\section{METHODS}

Heavy-mineral analysis of the sand fraction of 29 samples was done following standard procedures: separation of the heavy minerals from the 3.5 to $3.0 \phi$ grain-size fraction $(88-125 \mu \mathrm{m})$ with bromoform of a density of $2.85 \mathrm{~g} / \mathrm{cm}^{3}$, removal of magnetite with a hand-magnet, and mounting of a split sample on a glass slide with Canada balsam (refractive index $n=1.54$ ). In addition, one set of heavy-mineral mounts was prepared for microprobe analysis using Hilquest thin-section epoxy.

Two hundred nonopaque, nonmicaceous heavy minerals were identified per sample using the energy dispersive spectrometer (EDS) of the electron microprobe; the same number of grains was identified optically in 18 samples with a polarizing microscope. Analysis of heavy minerals with the electron microprobe provided a fast method of identification and counting, compared to the conventional method of using a polarizing microscope. Heavy-mineral analysis using the electron microprobe has its drawbacks, however. As grain mounts cannot be highly polished without losing grains, only a qualitative analysis of grain composition is possible. Thus in the case of minerals such as olivines and pyroxenes, which exhibit solid solution between two end members, a particular mineral species has not been identified; and only approximate chemical boundaries were drawn on the basis of the ratio of end-member compositions. Another inherent drawback is that physical properties of the mineral, such as grain morphology, inclusions, and diagenetic alterations, are not taken into account. Such properties at times can be very helpful in determining provenance and understanding changes in the modal composition of the suites. Therefore, a combination of microprobe analysis and traditional optical investigation with the petrographic microscope is recommended.

In the case of light-mineral mounts, the grains were first stained with sodium cobaltinitrite and then with rhodizonate reagent for the identification of potassium feldspar and plagioclase, respectively. For light-mineral analysis, 200 grains per sample from the 88- to $125-\mu \mathrm{m}$ ' size fraction (3.5-3.0 $\phi$ ) were counted under the polarizing microscope. 


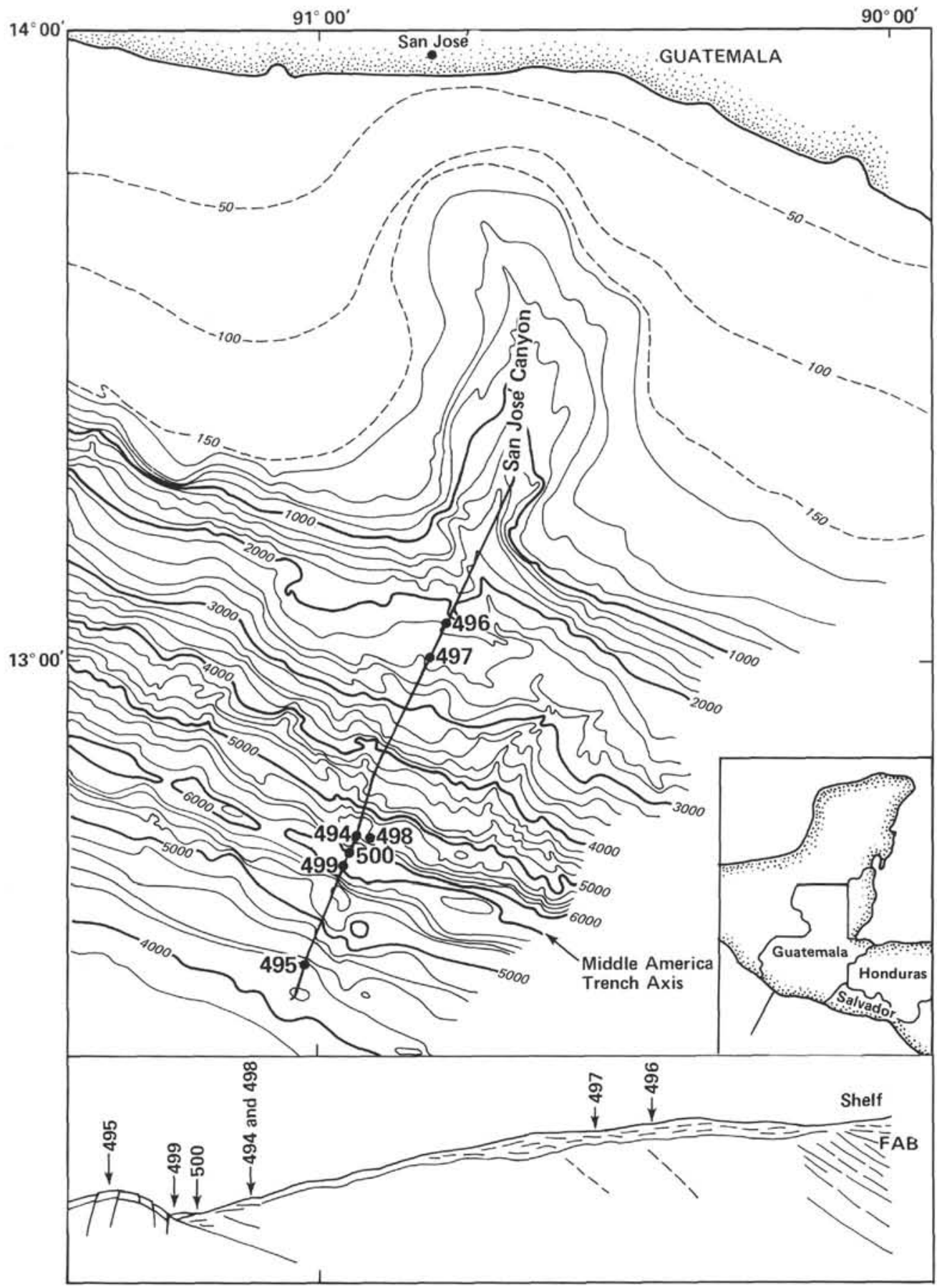

Figure 1. Location map for DSDP Leg 67 sites off Guatemala and cross-section based on University of Texas Marine Science Institute (UTMSI) multichannel seismic reflection profile (after R. von Huene and J. Aubouin, 1980). (FAB = forearc basin.)

\section{HEAVY-MINERAL COMPOSITION OF SANDS FROM LEG 67 SITES}

Compositionally immature heavy-mineral assemblages dominated by pyroxenes and amphiboles with admixtures of olivines and epidotes characterize the sands from the Leg 67 sites. Minerals such as sphene, rutile, and apatite are present in trace amounts. A detailed list of grain percentages for each sample is provided in
Tables 1 and 2. In the following section, results are presented by drill sites grouped into tectonic provinces.

\section{Slope Sites}

\section{Site 494}

Site 494 is located on the lower slope of the Middle America Trench off Guatemala only $4 \mathrm{~km}$ away from and about 600 meters above the Trench floor. It is 
Table 1. Heavy-mineral analyses for DSDP Leg 67 samples.

\begin{tabular}{|c|c|c|c|c|c|c|c|c|c|c|c|c|c|c|c|c|}
\hline \multirow{2}{*}{$\begin{array}{c}\text { Sample } \\
\text { (interval in } \mathrm{cm} \text { ) }\end{array}$} & \multicolumn{4}{|c|}{ Orthopyroxene } & \multicolumn{4}{|c|}{ Clinopyroxene } & \multirow[b]{2}{*}{ Amphiboles } & \multirow[b]{2}{*}{ Olivine } & \multirow[b]{2}{*}{ Epidote } & \multirow[b]{2}{*}{ Sphene } & \multirow[b]{2}{*}{ Rutile } & \multirow[b]{2}{*}{ Apatite } & \multirow{2}{*}{$\begin{array}{l}\text { Total No. } \\
\text { of Grains } \\
\text { Counted } \\
\text { per Sample }\end{array}$} & \multirow{2}{*}{$\begin{array}{l}\text { Age of } \\
\text { Sample }\end{array}$} \\
\hline & $\mathrm{Mg}>\mathrm{Fe}$ & $\mathrm{Mg}=\mathrm{Fe}$ & $\mathrm{Mg}<\mathrm{Fe}$ & $\Sigma$ & $\mathrm{Mg}>\mathrm{Fe}$ & $\mathrm{Mg}=\mathrm{Fe}$ & $\mathrm{Mg}<\mathrm{Fe}$ & $\Sigma$ & & & & & & & & \\
\hline $494-1-2,109-114$ & 19 & 4 & 5 & 28 & 22 & 6 & 2 & 30 & 33 & 1 & 6 & 2 & 0 & 0 & 200 & late Quaternary \\
\hline $494-3-3,109-113$ & 18 & 5 & 4 & 27 & 20 & 5 & 3 & 28 & 38 & $i$ & 5 & 1 & 0 & 0 & 200 & Quaternary \\
\hline $494 \mathrm{~A}-1-2,87-91$ & 15 & 4 & 6 & 25 & 20 & 6 & 4 & 30 & 42 & 0 & 3 & 0 & 0 & 0 & 200 & Quaternary \\
\hline $494 A-2-1,61-65$ & 20 & 4 & 4 & 28 & 21 & 6 & 4 & 31 & 36 & 1 & 3 & 1 & 0 & 0 & 200 & Quaternary \\
\hline $494 \mathrm{~A}-20-1,76-78$ & 16 & 5 & 5 & 26 & 11 & 5 & 4 & 20 & 50 & 0 & 3 & 1 & 0 & 0 & 200 & early Pliocene \\
\hline $498 \mathrm{~A}-13-1,13-18$ & 31 & 1 & 0 & 32 & 16 & 0 & 1 & 17 & 10 & 0 & 39 & 1 & 1 & 0 & 200 & Miocene \\
\hline $498 \mathrm{~A}-15-1,143-147$ & 6 & 0 & 0 & 6 & 19 & 0 & 1 & 20 & 1 & 0 & 68 & 1 & 3 & 1 & 200 & Miocene \\
\hline $498 \mathrm{~A}-15-2,118-123$ & 44 & 2 & 2 & 48 & 31 & 0 & 0 & 31 & 1 & 0 & 18 & 0 & 1 & 1 & 200 & Miocene \\
\hline $499-5-6,12-16$ & 37 & 4 & 1 & 42 & 25 & 0 & 1 & 26 & 16 & 4 & 11 & 0 & 1 & 0 & 200 & late Quaternary \\
\hline $499-6-4,132-134$ & 24 & 4 & 1 & 29 & 33 & 6 & i & 40 & 25 & 0 & 5 & 0 & 1 & 0 & 200 & late Quaternary \\
\hline $499-7-4,94-96$ & 25 & 3 & 1 & 29 & 30 & 1 & 0 & 31 & 32 & 2 & 5 & 0 & 1 & 0 & 200 & late Quaternary \\
\hline $499-9-1,90-92$ & 27 & 7 & 1 & 35 & 25 & 4 & 1 & 30 & 29 & 6 & 0 & 0 & 0 & 0 & 200 & late Quaternary \\
\hline $499-10-2,115-117$ & 23 & 3 & 2 & 28 & 34 & 1 & 1 & 36 & 17 & 17 & I & 0 & 1 & 0 & 200 & late Quaternary \\
\hline $499-11-1,81-85$ & 31 & 2 & 2 & 35 & 26 & 4 & 3 & 33 & 22 & 9 & i & 0 & 0 & 0 & 200 & late Quaternary \\
\hline $499-11-3,117-119$ & 20 & 10 & 3 & 33 & 20 & 6 & 2 & 28 & 25 & 10 & 2 & 1 & 1 & 0 & 200 & late Quaternary \\
\hline $499-12-3,124-128$ & 21 & 7 & 5 & 33 & 28 & 6 & 3 & 37 & 23 & 5 & 1 & 0 & 0 & 1 & 200 & late Quaternary \\
\hline $499-13-5,140-142$ & 23 & 2 & 1 & 26 & 34 & 1 & 0 & 35 & 16 & 16 & 3 & 0 & 3 & 1 & 200 & late Quaternary \\
\hline $500-3-5,33-35$ & 23 & 5 & 10 & 38 & 32 & 4 & 2 & 38 & 16 & 1 & 6 & 0 & 1 & 0 & 200 & late Quaternary \\
\hline $500-4-2,118-120$ & 17 & 6 & 4 & 27 & 28 & 6 & 4 & 38 & 28 & 4 & 2 & 0 & 1 & 0 & 200 & late Quaternary \\
\hline $500-7-6,87-89$ & 17 & 1 & 3 & 21 & 33 & 4 & 2 & 39 & 20 & 18 & 1 & 0 & 1 & 0 & 200 & late Quaternary \\
\hline $500-8, \mathrm{CC}(34-36)$ & 23 & 3 & 1 & 27 & 35 & 0 & 2 & 37 & 24 & 10 & 2 & 0 & 0 & 0 & 200 & late Quaternary \\
\hline $500-9-1,2-6$ & 18 & 6 & 3 & 27 & 33 & 3 & 3 & 39 & 25 & 6 & 2 & 0 & 0 & 1 & 200 & late Quaternary \\
\hline $500-9-2,39-43$ & 22 & 4 & 3 & 29 & 27 & 4 & 2 & 33 & 26 & 7 & 4 & 0 & 0 & 1 & 200 & late Quaternary \\
\hline $500-9-7,62-66$ & 19 & 6 & 1 & 26 & 35 & 4 & 6 & 45 & 19 & 5 & 3 & i & 0 & 1 & 200 & late Quaternary \\
\hline $500-10-1,8-84$ & 20 & 7 & $i$ & 28 & 30 & 6 & 2 & 38 & 24 & 6 & 3 & 0 & 1 & 0 & 200 & late Quaternary \\
\hline
\end{tabular}

Note: Figures are grain percentages from electron microprobe counts. $\Sigma$ indicates row total.

Table 2. Heavy-mineral percentages for DSDP Leg 67 sites determined with petrographic microscope.

\begin{tabular}{|c|c|c|c|c|c|c|c|c|c|c|c|}
\hline $\begin{array}{c}\text { Sample } \\
\text { (interval in } \mathrm{cm} \text { ) }\end{array}$ & Hypersthene & Augite & Pigeonite & Hornblende & Olivine & Epidote & Sphene & Rutile & Apatite & $\begin{array}{c}\text { Total No. } \\
\text { of Grains } \\
\text { Counted } \\
\text { per Sample }\end{array}$ & $\begin{array}{l}\text { Age of } \\
\text { Sample }\end{array}$ \\
\hline $494-1-2,109-114$ & 31 & 30 & 2 & 28 & 1 & 4 & 3 & 1 & 0 & 200 & late Quaternary \\
\hline $494 A-20-1,76-78$ & 29 & 24 & 1 & 41 & 1 & 2 & 1 & 0 & 1 & 200 & early Pliocene \\
\hline $498 \mathrm{~A}-13-1,13-18$ & 35 & 13 & 0 & 8 & 0 & 41 & 0 & 3 & 0 & 200 & Miocene \\
\hline $498 \mathrm{~A}-15-1,143-147$ & 11 & 10 & 0 & 3 & 0 & 71 & 0 & 5 & 0 & 200 & Miocene \\
\hline $498 \mathrm{~A}-15-2,118-123$ & 40 & 34 & 2 & 6 & 0 & 16 & 0 & 2 & 0 & 200 & Miocene \\
\hline $499-5-6,12-16$ & 38 & 36 & 0 & 13 & 2 & 8 & 1 & 1 & 1 & 200 & late Quaternary \\
\hline $499-6-4,132-134$ & 32 & 35 & 3 & 23 & 3 & 3 & 1 & 0 & 0 & 200 & late Quaternary \\
\hline $499-7-4,94-96$ & 25 & 33 & 1 & 34 & 1 & 4 & 1 & 0 & 1 & 200 & late Quaternary \\
\hline $499-9-1,90-92$ & 39 & 23 & 3 & 26 & 3 & 3 & 1 & 1 & 1 & 200 & late Quaternary \\
\hline $499-10-2,115-117$ & 31 & 32 & 2 & 20 & 12 & 0 & 0 & 2 & 1 & 200 & late Quaternary \\
\hline $499-11-1,81-85$ & 35 & 26 & 3 & 27 & 6 & 1 & 1 & 1 & 0 & 200 & late Quaternary \\
\hline $499-11-3,117-119$ & 30 & 30 & 1 & 23 & 13 & 2 & 0 & 1 & 0 & 200 & late Quaternary \\
\hline $499-12-3,124-128$ & 32 & 34 & 3 & 20 & 9 & 2 & 0 & 0 & 0 & 200 & late Quaternary \\
\hline $499-13-5,140-142$ & 25 & 35 & 1 & 19 & 13 & 4 & 1 & 1 & 1 & 200 & late Quaternary \\
\hline $500-3-5,33-35$ & 34 & 40 & 1 & 13 & 5 & 4 & 1 & 1 & 1 & 200 & late Quaternary \\
\hline $500-4-2,118-120$ & 25 & 35 & 3 & 30 & 2 & 3 & 1 & 0 & 1 & 200 & late Quaternary \\
\hline $500-7-6,87-89$ & 22 & 34 & 3 & 21 & 15 & 3 & 1 & 1 & 0 & 200 & late Quaternary \\
\hline $500-8, \mathrm{CC}(34-36)$ & 25 & 36 & 1 & 21 & 12 & 4 & 1 & 0 & 0 & 200 & late Quaternary \\
\hline
\end{tabular}

Note: Compare this table with Table 1.

situated on a terrace $2 \mathrm{~km}$ wide and at least $18 \mathrm{~km}$ long (Figs. 1, 2).

Due to the paucity of sand at this site, only 5 samples could be processed. Pyroxenes (dominantly hypersthene and augite) and amphiboles (green brown hornblende) are most abundant (Table 1). Epidote constitutes a minor fraction, and sphene is present in trace amounts. In the Quaternary samples, pyroxenes and amphiboles occur in a 2:1 ratio, whereas in some of the lower Pliocene samples, the ratio is closer to $1: 1$.

By optical examination of the various mineral species, the following characteristics were observed. Hypersthene exhibits pleochroism in shades of pale green $(\mathrm{Y}, \mathrm{Z})$ to a very subtle hue of pinkish brown $(\mathrm{X}) ; 2 \mathrm{~V}$ is approximately $60^{\circ}$. The crystal habit ranges from tabular to prismatic; minute opaque inclusions, possibly of magnetite, are very common. The majority of these crystals is fresh and unaltered, although some show signs of etching at the termination of the prism planes. This mild etching suggests the beginning stages of a diagenetic breakdown of the pyroxenes. Some of the hypersthene crystals show limonitic (goethite/hematite) coating on crystal faces. This limonitic alteration differs from diagenetic dissolution in that it is produced in an oxidizing subaerial weathering environment.

Augite occurs as pale green (X) to pale brownish green $(\mathrm{Y}, \mathrm{Z})$ crystals with a stubby morphology that is much more common than the prismatic form. The optic 


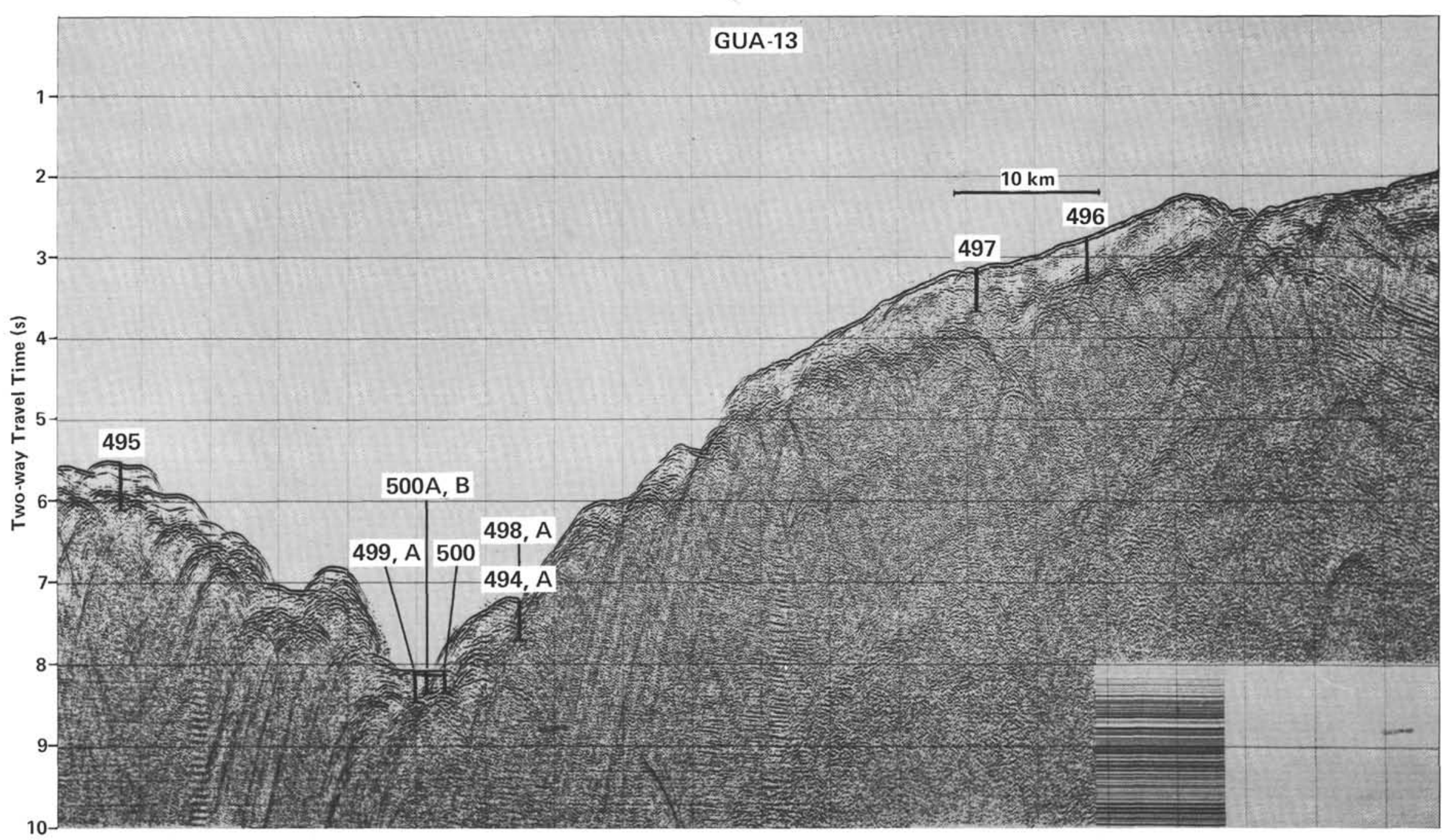

Figure 2. Seismic profile GUA-13, Guatemala transect (from Ibrahim et al., 1979) showing position of Leg 67 holes. 
angle is 45 to $50^{\circ}$; the extinction angle is $Z \wedge c \approx 45^{\circ}$. Other characteristics such as etching and limonitic coatings are similar to those of hypersthene. Pigeonite appears as small stubby grains with irregular terminations, some of which are rounded. The optic angle is 25 to $30^{\circ}$, the extinction angle $Z \wedge c \approx 35^{\circ}$. Signs of alteration are generally lacking, but the crystals commonly exhibit a dusting of minute opaque inclusions. Pigeonite is the least abundant of the pyroxenes.

The amphibole in the heavy-mineral assemblage at this site is a green brown variety of hornblende that exhibits very strong pleochroism between deep olive green $(\mathrm{X})$ and deep brown $(\mathrm{Z})$, an optic angle of $70^{\circ}$, and a 13 to $18^{\circ}$ extinction angle $Z \wedge c$. Long prismatic crystals are very common. The crystals are largely fresh and unaltered, although mildly etched crystals do occur. Limonitic coating, as seen in the pyroxenes, is rare to absent.

The olivines are colorless to faint yellowish green subrounded crystals. Some of these crystals have colorless inclusions in the shape of minute rods and lenses. Almost all grains show a limonitic coating.

\section{Site 498}

Site 498 is located on the landward slope of the Middle America Trench in about 5440 meters water depth. It is about 600 meters above and $4 \mathrm{~km}$ from the Trench floor on the same narrow terrace as Site 494; Site 498 is $0.8 \mathrm{~km}$ east-southeast (ESE) from Site 494 on a line parallel to the Trench axis (Figs. 1,2).

The objective at this site was to drill the deeper sedimentary section not penetrated at Site 494, a goal that was not achieved. To avoid coring the upper 200 -meterthick Quaternary sediments again, which were expected to be very similar to those at Site 494 , most of this interval was washed down during drilling. Three Miocene samples from the deeper horizons of Hole 498A were processed. The heavy-mineral suite is not identical to that at Site 494. Epidote constitutes a significant proportion, ranging from 18 to $70 \%$ of the nonopaque heavy minerals present. Pyroxenes are second in abundance, whereas amphibole proportions are small. Heavy minerals such as sphene, rutile, and apatite are present in trace amounts (Table 1); olivine is absent.

Etching of the unstable components (pyroxenes and amphiboles) has proceeded to varying degrees, depending on the mineral species and also on their depth in the stratigraphic column. The absence of olivine is probably due to its selective removal from the assemblage during early diagenetic intrastratal solution. An increase in the degree of etching with burial depth is exhibited by Sections 498A-13-1 and 498A-15-1. Samples from Core 13, Section 1 ( $285 \mathrm{~m}$ sub-bottom depth) contain moderately etched pyroxenes and amphiboles, whereas the sample from Core 15, Section 1 (17 m below Core 13, Section 1) shows heavily etched pyroxenes and amphiboles. In this particular case amphiboles (hornblendes) appear to be more susceptible to etching by intrastratal solution than do pyroxenes. Those parts of the grain where relief is highest and surface area greatest are likely to be most intensively affected by intrastratal solution. In the case of hornblende, these parts are the terminations with their cleavage intersection. Etching works inward from these terminations, stripping the cleavage planes one by one. If this process is carried to completion, the entire grain disappears. Otherwise, the process leaves behind fragile, skeletal-looking grains with hacksaw terminations (Plate 1, Figs. 1, 2).

Section 498A-15-2 contains only a relatively small percentage of epidote $(19 \%)$ and significantly higher proportions of pyroxene and amphibole (Table 1). Microscopic examination of this sample revealed euhedral crystals of pyroxenes (Plate 1, Fig. 3) and amphiboles enveloped in clear volcanic glass. Because the glass enveloping these crystals would have likely been abraded during fluvial transport, these crystals were probably deposited during an ash fall. This interpretation is supported by the composition of the light fraction, which in this case is almost entirely vesicular glass characteristic of an ashfall deposit (Plate 1, Fig. 5). The glass appears to encapsulate the unstable pyroxene and amphibole grains, forming a protective coating and thereby impeding the action of intrastratal solution on the grains. In contrast, the sands from Sections 498A-13-1 and 498A-15-1 were most likely transported by rivers and longshore currents before being brought to the deep sea, and glass envelopes, if any, would have been abraded, thus leaving the crystals bare for attack by the pore fluids. Different provenance explains the smaller proportion of epidote and the larger proportion of pyroxene and amphibole in Section 498A-15-2 compared to Sections 498A-13-1 and 498A-15-1.

\section{Trench Sites}

\section{Site 499}

Site 499 is located in a water depth of 6125 meters on the floor of the Middle America Trench off Guatemala, which is approximately $2.3 \mathrm{~km}$ wide at this point. The site is located $1 \mathrm{~km}$ from the outer (seaward) Trench wall (Figs. 1, 2).

Nine samples representing approximately 120 meters of Quaternary sediments were analyzed from this site. Five of these nine, namely Sections 499-6-4, -7-4, -9-1, $-11-1$, and $-11-3$, are sandy trench-fill turbidites, whereas the other four, Sections 499-5-6, -10-2, -12-3, and -13-5, are turbiditic and hemipelagic muds. The heavy-mineral composition of the two groups of samples is almost identical, consisting of pyroxenes (dominantly hypersthene and augite), amphiboles (green brown hornblende), and lesser amounts of epidote and olivine. Pyroxenes and amphiboles together constitute more than $90 \%$ of the assemblage and are present in an average ratio of $3: 1$ (Table 1). The heavy-mineral assemblages of this site are similar to those of Site 494 on the lower slope, indicating a common provenance for the Quaternary and Pliocene sediments of both sites.

\section{Site $\mathbf{5 0 0}$}

Site 500 is located at the transition of the landward slope of the Middle America Trench to the Trench floor (Figs. 1, 2) at a water depth of 6100 meters.

The 8 heavy-mineral assemblages from the 75 -meterthick Quaternary sequence at this site are identical to those found at Site 499 and consist of an immature 
pyroxene-amphibole association with lesser amounts of epidote and olivine (Table 1). Sphene, rutile, and apatite are present in trace amounts. Tests of foraminifers and radiolarians filled with or partly replaced by pyrite are abundant.

\section{Oceanic Crust}

\section{Site 495}

Four Quaternary samples were processed from Site 495 , located on the oceanic crust $22 \mathrm{~km}$ seaward of the Trench axis and about 192 meters above it. These samples yielded insignificant amounts of heavy minerals.

\section{LIGHT-MINERAL COMPOSITION OF SANDS FROM LEG 67 SITES}

The light fraction of the sands from Leg 67 sites is dominantly composed of volcanic glass and plagioclase feldspar (Table 3). Potash feldspar is present in minor amounts in some samples. No aphanitic rock fragments were observed in the 88 - to $125-\mu \mathrm{m}$ fraction (i.e., the feldspars occur as individual grains). Glauconite, biotite, and quartz occur in trace amounts.

Glass and plagioclase in varying proportions constitute about $90 \%$ of the light-mineral assemblage along the lower slope and Trench. The only exception to this type of composition is Section 498A-15-2, which is coarse vitric sand and consists almost entirely of glass. The glass appears as angular shards and as vesicular fragments. The plagioclase frequently exhibits oscillatory zoning. In such cases, there is occasionally an unconformity between successive growth zones (Plate 1, Fig. 4). Such growth unconformity indicates a volcanic source and represents an episode of magmatic corrosion followed by repeated episodes of crystal growth prior to violent expulsion from the magma chamber. Anorthite content of the growth zones varies from $45 \%$ (maximum-51\%) at the center to $7 \%$ (minimum-3\%) at the rim, as determined from extinction angles.
The light minerals recovered at Site 495 are different from those found on the lower slope and in the Trench. The sand fraction consists almost entirely of light minerals, biogenic components (foraminifers, radiolarians, sponge spicules, etc.), and volcanic glass in varying proportions. Abundant, large, euhedral crystals of gypsum occur in hemipelagic sediments (Section 495-5-3) (Plate 1, Fig. 6).

\section{DISCUSSION}

Results of heavy- and light-mineral analyses show an essentially identical mineralogy for the sediments of all DSDP Leg 67 sites along the lower slope and Trench. These sediments are essentially immature pyroxene-amphibole assemblages in the heavy fraction (Fig. 3) and volcanic glass and commonly zoned plagioclase in the light fraction (Fig. 3).

The heavy minerals of Hole 498A Miocene sediments are, however, different from those of the other holes because the Hole 498A samples display the effects of selective removal of unstable sedimentary components such as olivine and, to a lesser extent, pyroxene and amphibole by intrastratal solution. Consequently, the more stable epidote is enriched. This is a common phenomenon amply documented and discussed in the literature (Pettijohn, 1941; 1975, p. 491; Smithson, 1941; van Andel, 1959). Given sufficient time, the unstable population would eventually be entirely removed. Thus, even though their present modal mineralogy differs from that of the younger deposits, these Miocene sediments had originally essentially the same composition as the Quaternary deposits.

Guatemala is located at a convergent lithospheric plate junction. In the southwestern part of Guatemala, the coastal plain is about $30 \mathrm{~km}$ wide and extends from the shoreline of the Pacific to the volcanic province in the north. High rainfall generates high sedimentation rates, leading to the formation of active flood plains that cover most of the coastal area with a blanket of

Table 3. Light-mineral percentages for DSDP Leg 67 sites.

\begin{tabular}{|c|c|c|c|c|c|c|c|c|c|}
\hline $\begin{array}{c}\text { Sample } \\
\text { (interval in } \mathrm{cm} \text { ) }\end{array}$ & $\begin{array}{c}\text { Volcanic } \\
\text { Glass }\end{array}$ & Plagioclase & K-Feldspar & Quartz & Glauconite & Biotite & $\begin{array}{c}\text { Total No. } \\
\text { of Grains } \\
\text { Counted per } \\
\text { Sample }\end{array}$ & $\begin{array}{l}\text { Age of } \\
\text { Sample }\end{array}$ & $\begin{array}{l}\text { Sub-bottom } \\
\text { Depth } \\
\text { (m) }\end{array}$ \\
\hline $494-1-2,109-114$ & 61 & 34 & 3 & 1 & 1 & 0 & 200 & late Quaternary & 2.6 \\
\hline $494-3-3,109-113$ & 64 & 33 & 1 & 1 & 0 & 1 & 200 & Quaternary & 21.6 \\
\hline $494 \mathrm{~A}-1-2,87-91$ & 44 & 54 & 2 & 0 & 0 & 0 & 200 & Quaternary & 39.9 \\
\hline $494 \mathrm{~A}-2-1,61-65$ & 31 & 44 & 3 & 1 & 0 & 1 & 200 & Quaternary & 47.6 \\
\hline $494 \mathrm{~A}-20-1,76-78$ & 55 & 41 & 3 & 0 & 1 & 0 & 200 & early Pliocene & 218.7 \\
\hline $498 \mathrm{~A}-13-1,13-18$ & 20 & 72 & 5 & 1 & 2 & 0 & 200 & Miocene & 288.1 \\
\hline $498 \mathrm{~A}-15-1,143-147$ & 49 & 42 & 7 & 1 & 0 & 1 & 200 & Miocene & 308.4 \\
\hline $498 \mathrm{~A}-15-2,118-123$ & 93 & 5 & 2 & 0 & 0 & 0 & 200 & Miocene & 309.7 \\
\hline $499-5-6,12-16$ & 32 & 63 & 1 & 1 & 1 & 2 & 200 & late Quaternary & 36.6 \\
\hline $499-6-4,132-134$ & 41 & 48 & 6 & 2 & 3 & 0 & 200 & late Quaternary & 44.3 \\
\hline $499-7-4,94-96$ & 44 & so & 4 & 1 & i & 0 & 200 & late Quaternary & 53.4 \\
\hline $499-9-1,90-92$ & 23 & 72 & 3 & 0 & 2 & 0 & 200 & late Quaternary & 67.9 \\
\hline $499-10-2,115-117$ & 28 & 64 & 6 & 1 & 1 & 0 & 200 & late Quaternary & 79.1 \\
\hline $499-11-1,81-85$ & 46 & 46 & 6 & i & $i$ & 0 & 200 & late Quaternary & 86.8 \\
\hline $499-11-3,117-119$ & 27 & 60 & 11 & 2 & 0 & 0 & 200 & late Quaternary & 90.1 \\
\hline $499-12-3,124-128$ & 26 & 64 & 9 & 0 & 0 & 1 & 200 & late Quaternary & 99.7 \\
\hline $499-13-5,140-142$ & 61 & 30 & 5 & 1 & 1 & 2 & 200 & late Quaternary & 112.4 \\
\hline $500-3-5,33-35$ & 19 & 72 & 6 & 1 & 2 & 0 & 200 & Quaternary & 20.3 \\
\hline $500-4-2,118-120$ & 42 & 51 & 5 & 0 & 2 & 0 & 200 & Quaternary & 26.2 \\
\hline $500-7-6,87-89$ & 66 & 30 & 4 & 0 & 0 & 0 & 200 & Quaternary & 60.3 \\
\hline $500-8, \mathrm{CC}(34-36)$ & 46 & 44 & 7 & 1 & 2 & 0 & 200 & Quaternary & 70.8 \\
\hline $500-9-1,2-6$ & 40 & 55 & 4 & 0 & I & 0 & 200 & Quaternary & 71.0 \\
\hline $500-9-2,39-43$ & 48 & 46 & 4 & 0 & i & 1 & 200 & Quaternary & 72.9 \\
\hline $500-9-7,62-66$ & 55 & 40 & 4 & 1 & 0 & 0 & 200 & Quaternary & 80.5 \\
\hline $500-10-1,80-84$ & 46 & so & 3 & 0 & i & 0 & 200 & Quaternary & 81.3 \\
\hline
\end{tabular}




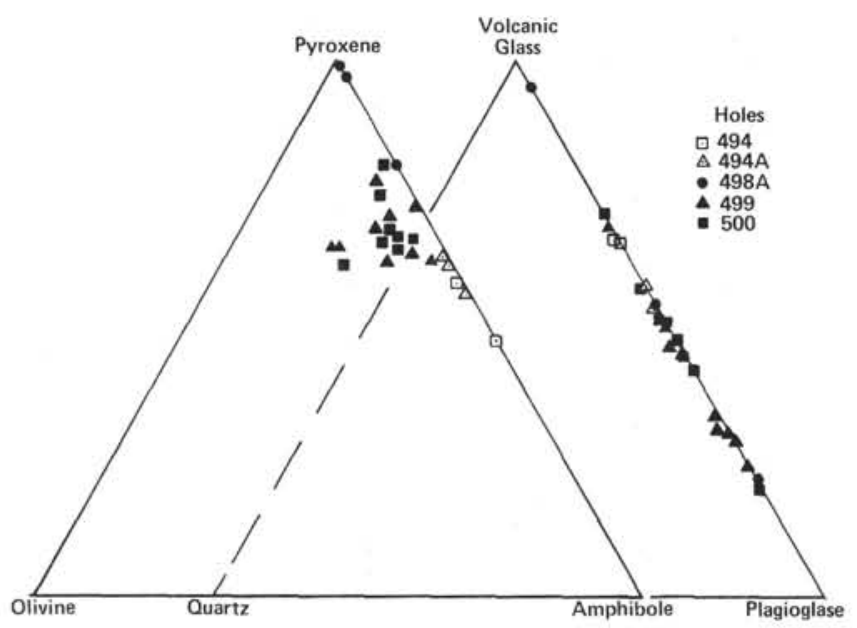

Figure 3. Heavy- and light-mineral assemblages from Leg 67, Middle America Trench transect. Data from Tables 1 and 3.

Quaternary volcanogenic deposits (Davies et al., 1979). This alluvium is continually transferred by a number of rivers, which discharge their load into the Pacific Ocean. The San José Canyon, along the strike of which the Leg 67 traverse is located (Fig. 1), is one of the possible major gateways allowing the coastal alluvial sediment to enter the Middle America Trench. Davies et al. (1979) studied the Holocene volcaniclastics in three forearc basins of Guatemala. Like the samples from Leg 67 sites, the mineralogy of those volcaniclastics is characterized by a high percentage of unstable components: pyroxenes, amphiboles, volcanic glass, and feldspars.

The mineralogy of all the Leg 67 samples from sites along the lower slope and Trench indicates a source area in the highland volcanic province of Guatemala. Once offshore, most sediments are probably transported along conduits such as the San José Canyon by mechanisms of rapid mass movement (e.g., turbidity currents or slumps and slides). Underconsolidated, water-rich Quaternary sediments may move by slumping, events triggered by frequent seismic events on this tectonically active margin. A third mode of downslope sediment movement may be "creep," occurring as a result of the rheological properties of the sediment. A fourth mode of transport is by dilute suspension currents or nepheloid layers (Azéma et al., Heinemann and Füchtbauer, this vol- ume). Finally, deposition from ash falls and eolian suspension occurs.

The occurrence of gypsum at 40 meters sub-bottom depth in Quaternary hemipelagic sediments of Hole 495 is enigmatic. Anhydrite precipitation has been described as an effect of hydrothermal alteration of oceanic crust (quoted in Fyfe et al., 1978), but it is difficult to see how this would occur at a site as far away from the midocean ridge as Site 495 .

\section{ACKNOWLEDGMENTS}

This paper is an excerpt from an undergraduate thesis prepared by S. Prasad at McGill University. Financial assistance was provided by National Science and Engineering Research Council of Canada Grant A-7368. Participation of R. Hesse on Leg 67 of the Deep Sea Drilling Project was financially supported by the Deutsche Forschungsgemeinschaft.

\section{REFERENCES}

Davies, D. K., Almon, W. R., Bonis, S. B., and Hunter, B. E., 1979. Deposition and diagenesis of Tertiary-Holocene volcaniclastics, Guatemala. In Scholl, P. A., and Schluger, P. R. (Eds.), Aspects of Diagenesis: Soc. Econ. Paleontol. Mineral. Spec. Publ., 26: 281-306.

Fyfe, W. S., Price, N. J., and Thompson, A. B., 1978. Fluids in the Earth's Crust: Developm. Geochem. 1, Amsterdam (Elsevier).

Ibrahim, A. K., Latham, G. V., and Ladd, J., 1979. Seismic refraction and reflection measurements in the Middle America Trench offshore Guatemala. J. Geophys. Res., 84(B10):5643-5649.

Ladd, J. W., Ibrahim, A. K., McMillen, K. J., Matumoto, T., Latham, G. V., von Huene, R. E., Watkins, J. E., Moore, J. C., and Worzel, J. L., 1978. Tectonics of the Middle America Trench, offshore Guatemala [paper presented at the International Symposium on the Feb. 4, 1976 Guatemala Earthquake and the Reconstruction Process, Agency for Int. Develop., Guatemala City].

Pettijohn, F. J., 1941. Persistence of heavy minerals and geologic age. J. Geol., 49:610-625. Row).

Seely, D. R., 1979. The evolution of structural highs bordering major forearc basins. In Watkins, J. S., Montadert, L., and Dickerson, P. W. (Eds.), Geological and Geophysical Investigation of Continental Margins: Am. Assoc. Pet. Geol. Mem., 29:245-260.

Seely, D. R., Vail, P. R., and Walton, G. G., 1974. Trench-slope model. In Burk, C. A., and Drake, C. L. (Eds.), The Geology of Continental Margins: New York (Springer-Verlag), pp. 249-260.

Smithson, F., 1941. The alteration of detrital minerals in the Mesozoic rocks of Yorkshire. Geol. Mag., 78:97-112.

van Andel, Tj. H., 1959. Reflections on the interpretation of heavy mineral analyses. J. Sediment. Petrol., 29:153-163.

von Huene, R. E., and Aubouin, J., et al., 1980. Leg 67: The Deep Sea Drilling Project: The Mid-America Trench transect off Guatemala. Geol. Soc. Am. Bull., Pt. 1, 90(7):421-432. 


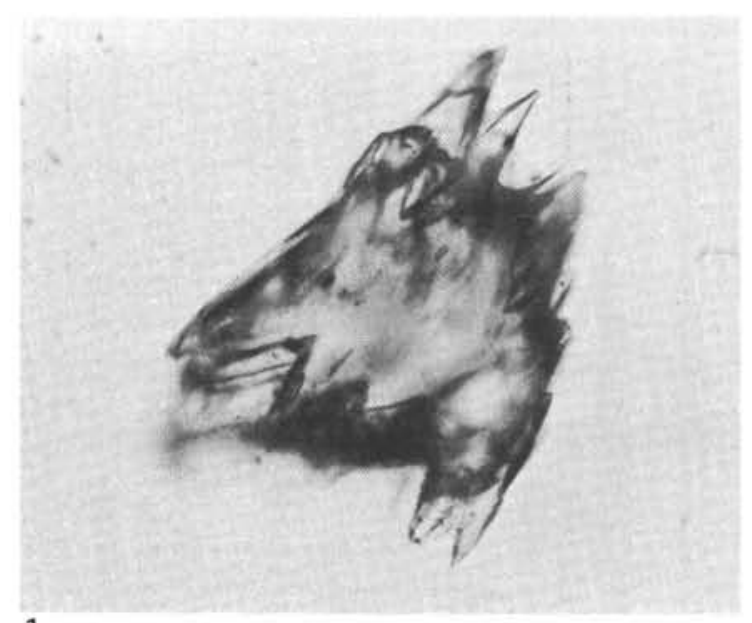

1

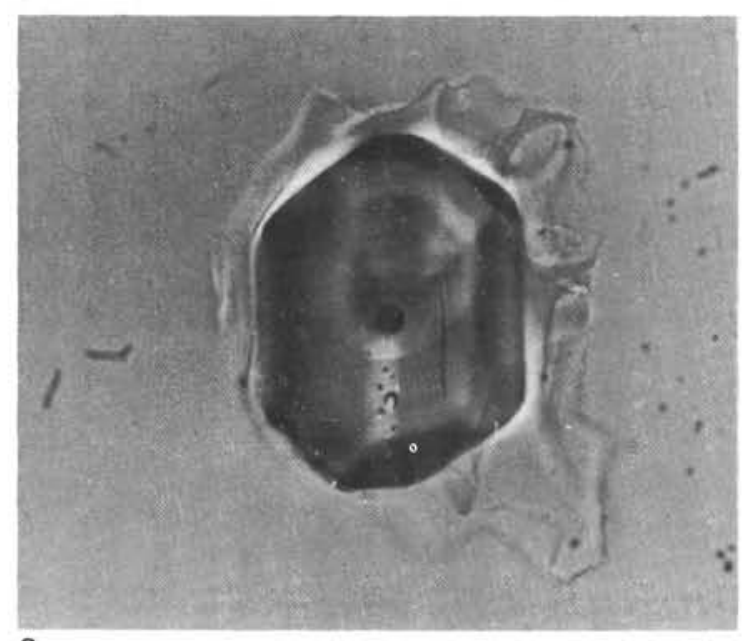

3

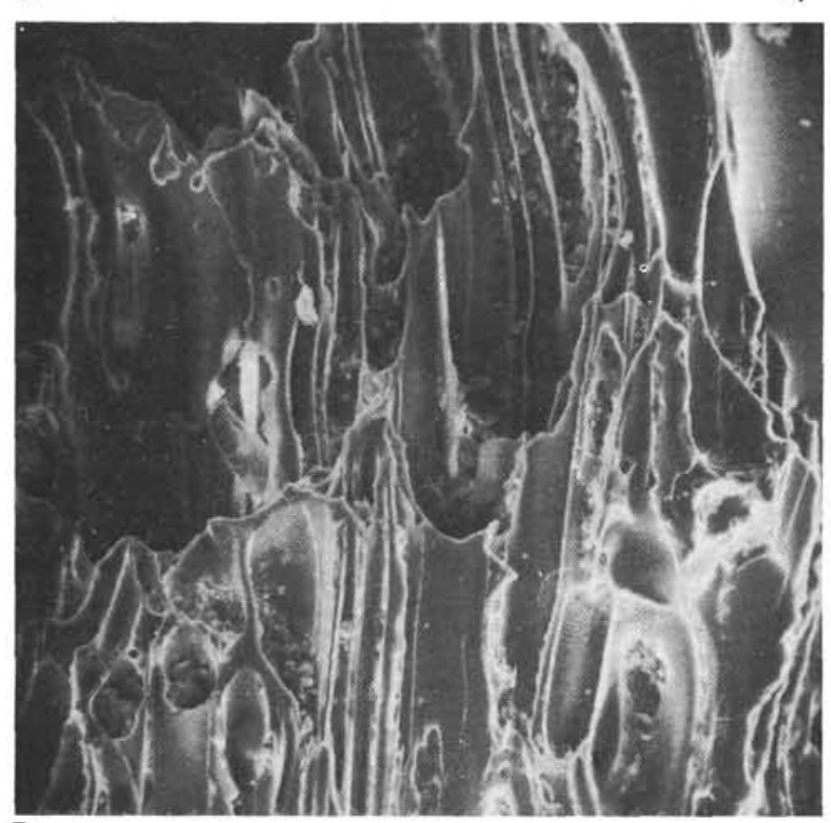

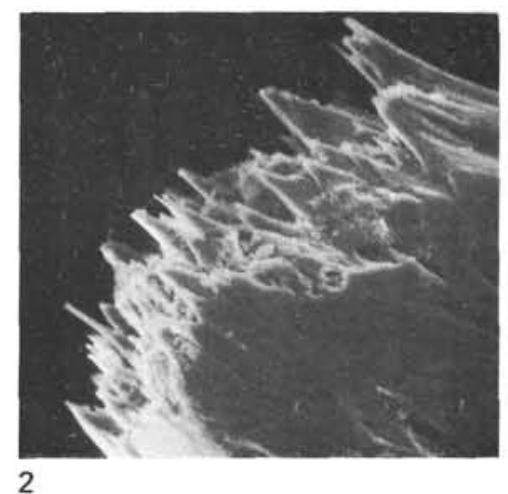

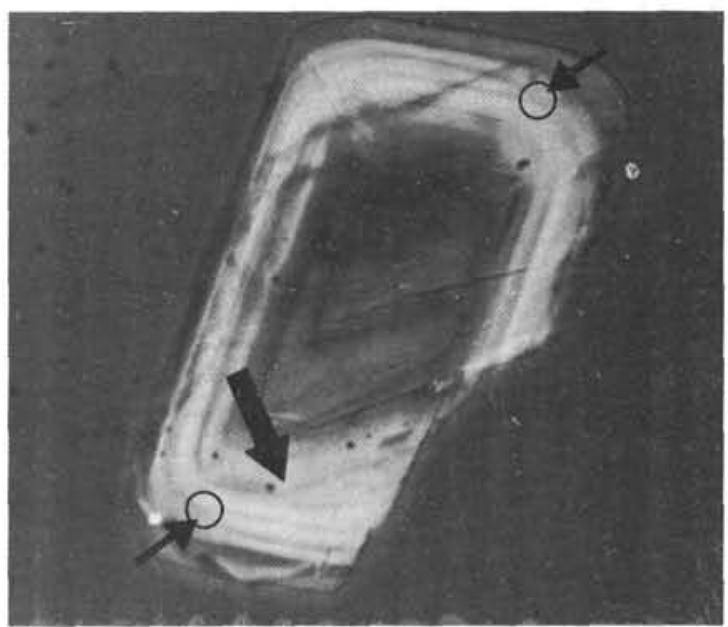

4

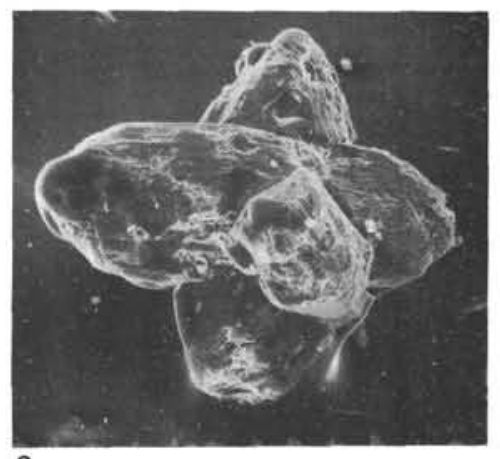

6

Plate 1. 1. Etched hornblende grain with hacksaw terminations. Section 498A-15-1. 2. SEM photo of hacksaw termination on hornblende grain. Section 498A-15-1. $\times 660$. 3. Pyroxene crystal enveloped in translucent volcanic glass. Section 498A-15-2. 4. Oscillatory zoning in plagioclase. Section 498A-15-2. (Core: An-45\%; rim: An-7\%. Unconformities [arrows] between successive growth zones reflect temporary magmatic corrosion.) 5. Vesicular volcanic glass fragment. Section 498A-15-2. 6. Twinned gypsum crystal. $\times 120$. Section 495-5-3. 